Горан Ј. Петровић

докторанд

Филолошки факултет

Универзитет у Београду
УДК

811.163.41'367.62

ДОИ

https://doi.org/10.18485/analiff.2016.28.2.10

\title{
О МЕТАФОРИЧНОЈ КОНЦЕПТУАЛИЗАЦИЈИ МУДРОСТИ У СРПСКОМ ЈЕЗИКУ
}

\begin{abstract}
Овај рад има за циљ да предочи начине на које се мудРост концептуализује у српском језику. У теоријском смислу, рад се заснива на савременој когнитивистичкој теорији појмовне метафоре. Три су конкретна циља овог истраживања: 1) да се установи списак изворних домена којима се концептуализује мудрост, 2) да се истакну метонимијски механизми помоћу којих долази до реализације уочених метафора, и 3 ) да се уоче сликовне метафоре код којих је мудрост, барем делимично, у улози циљног домена. За потребе дефинисања појма мудрости, послужили смо се тринаестом књигом Речни-

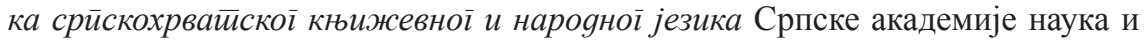
уметности (у тексту рада: РСАНУ) из 1988. године. Готово сви коришћени метафорички језички примери потичу из Елекииронскої корӣуса савременої срйскоі језика из 2013. године. Сви преостали преузети су из горе поменутог речника. На крају, рад ће пажњу посветити и разлици између позитивних и негативних конотативних вредности мудрости.
\end{abstract}

Кључне речи: појмовна метафора, сликовна метафора, метонимијска мотивација метафоре, концептуализација, мудрост, изворни домен, вертикална просторна схема.

\section{1. ТЕОРИЈСКИ ОКВИР}

1.1. О МЕТАФОРИ - Једно од кључних открића когнитивне лингвистике, чијем је развоју највећи допринос дала студија под насловом Metaphors we Live by Џорџа Лејкофа [George Lakoff] и Марка Џонсона [Mark Johnson], јесте закључак да метафора није само одлика елоквенције и украс шароликог књижевног језика, већ најпре је-

*_gphwchamp@gmail.com 
дан суштински, свеприсутни механизам човековог мишљења (Lakoff \& Johnson 1980). Овакав поглед на људско мишљење утемељен је на теоријском конструкту појмовне метафоре, чија „суштина јесте у разумевању и доживљавању једне ствари [појма] помоћу неке друге ствари [појма] (Lakoff \& Johnson 1980: 5)“. При томе, када говоримо искључиво о појмовној метафори, „разумевање и доживљавање појмова“" одвијају се искључиво на појмовној, менталној равни. Сликовне метафоре, које су у односу на појмовну метафору базичније по томе што за изворни и циљни домен немају појмове, већ, когнитивистички гледано, простије, чулима вида и слуха лако доступне слике (Кликовац 2008), за овај ће рад такође бити релевантне, али у знатно мањој мери.

Иначе, појмовне метафоре реализују се посредством метафоричких језичких израза, при чему основни образац појмовне метафоре гласи: А (циљни, апстрактни појмовни домен) ЈЕСТЕ Б (конкретнији, чулима сазнатљив изворни домен $)^{1}$. При реализацији метафора, између својстава, тј. конституентских елемената изворног и циљног домена долази до уочавања некаквих сличности, што затим омогућава појмовна пресликавања - основу за постанак сваке појмовне метафоре $^{2}$ (Lakoff \& Johnson 1980; Kövecses 2010).

За овај рад, поред појмовне и сликовне метафоре, која јесте наш кључни појам, релевантни ће бити и појмови оријентационе метафоре и појмовне метонимије. Међутим, о дефиницији ових концепата речи ће бити у каснијем делу рада, и то онда када сам текстуални садржај то буде захтевао. У наставку следи тумачење нашег циљног домена - мудрости.

\section{2. О МУДРОСТИ (РСАНУ) - Основно значење муяросиии гла-} си: „особина, својство онога који је мудар, уман, који је способан да

1 На пример, у метафоричком језичком изразу їорейи оg љубави реализована је појмовна метафора љУБАВ ЈЕ ВАТРА.

$2 \mathrm{У}$ метафоричком језичком изразу из прве фусноте може се уочити сличност између чињенице да заљубљена особа, услед доживљених физиолошких реакција, у телу осећа пријатну топлоту, и чињеница да ватра производи пријатну топлоту. Дакле, реч је о следећем појмовном пресликавању: топлота у телу заљубљене особе (својство циљог домена А) јесте топлота ватре (својство изворног домена Б). 
умно, зрело, интелигентно расуђује“ (РСАНУ 1988: 240). При томе, муgар јесте онај „који се одликује великом памећу, [који је] веома паметан, уман, разуман, разборит, разложан [1.a]“, као и онај „који садржи, одражава [...] искуство, [који је] заснован на искуству, знању [1.б.]“ (РСАНУ 1988: 233). Дакле, мудрост у својој основи подразуме-

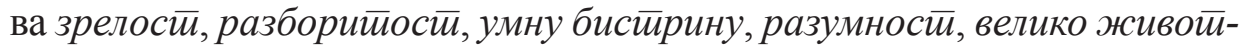
но искустиво и висок иниеелекйуални кайацийей. Јасно је да се ради о појму чијем се најосновнијем значењу приписује изразито позитивна евалуација.

Затим, друго значење мудрости, раслојено на две различите дефиниције, гласи: „2.а. мудро, паметно понашање, поступак“; „2.б. оно што је вешто, спретно изведено, вештина; довитљивост, лукавство“ (РСАНУ 1988: 240). Одавде сазнајемо да појам мудрости обухвата и

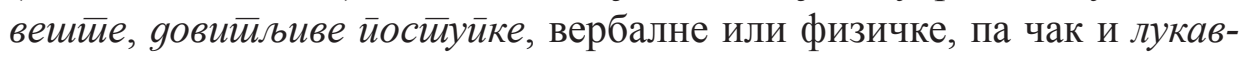
$c \bar{u} в о$, на које се каткада гледа уз негодовање, као на нешто непоштено - „Таква државничка мудрост за осуду је“ [пример за пододредницу 2.a.] (РСАНУ 1988: 240). Из ове две дефиниције, међутим, сазнајемо још нешто - а то је да се лексема муgрос $\bar{u}$ може користити по метонимијском начеЛУ ОСОБИНА ЗА ПОСТУПАК КОЈИМ СЕ ИЗРАЖАВА ОСОБИНА.

Такође, мудрост се може односити и на „3. наук[у], ученост, знање“", као и на ,4. филозофиј[у] као научн[у] дисциплин[у]“(РСАНУ 1988: 240), док под одредницом муgар налазимо и једно покрајинско значење: „који чува и цени материјалне вредности, штедљив, шкрт“ - „Мудар [у селу Краље, срез бихаћки] значи што и шкрт“ (РСАНУ 1988: 233).

Дакле, под мудрошћу се подразумевају сва она човекова својства које му омогућавају да, у телесном и душевном смислу, неозлеђено превазилази све препреке. Када се овоме појму дода још и списак синонима из Речника синонима Павла Ћосића, увид у семантички опсег мудрости постаје целовит: ,умносй, gубокоумље, високоумље, мисао-

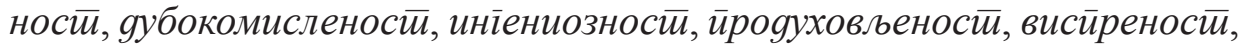
gубокоумносй, ояуховљеноси"“ (Ћосић 2008: 337). Из дотичног списка посебно наглашавамо речи попут продуховљености и одуховљености, које мудрости, поред већ поменуте рационалне, додају и духовну значењску димензију. 


\section{2. АНАЛИЗА КОРПУСА; МЕТОДОЛОГИЈА И ЦИЉЕВИ ИСТРАЖИВАҢА}

Већина коришћених језичких примера у овом раду потиче из следећег извора: 1) Елекйронски корйус савременої срӣскої језика из 2013. При томе, разматрани су само они случајеви у којима је лексема муярости (у различитим падежним облицима) експлицитно наведена. У том смислу, о квантитативном аспекту анализираног корпуса наводимо следеће: за облик „мудрост“ пронашли смо 945 примера, за облик „мудрости“ 1097 примера, док је за реч „мудрошћу“ пронађено 169 примера. У разматрање су узимани сви они језички примери код којих мудрост није употребљена у њеном основном речничком значењу.

Оновни циљ истраживања јесте да се уоче изворни домени који, при метафоричкој концептуализацији, структуришу наш појам. Споредни циљеви истраживања јесу: 1) да се препознају метонимијски механизми који омогућавају реализацију уочених метафора и 2) да се истакну сликовне метафоре код којих се мудрост појављује као циљни домен. Такође, желимо понешто рећи и о контрасту између негативне и позитивне конотативне вредности муяросии.

\section{3. КОНЦЕПТУАЛИЗАЦИЈА МУДРОСТИ}

3.1. МУДРОСТ ЈЕ ПРЕДМЕТ - Ова метафора се, ако ПРЕДМЕТ схватимо у његовом најопштијем смислу, може реализовати помоћу неколиких глаголских лексема. Мудрост се може може иматии, (не)

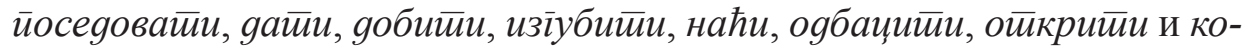
ристиити

1) Иако неписмена, имала је своју муgрости и свој начин понашања у животу (ЕК, Ј. Цвијић). 2) „Не вреди“, дометну, „не йосеgујемо више муярости старих, окончало се раздобље дивова“ (ЕК, У. Еко)! 3) Због свега тога, Сократ се с разлогом пита: „Да ли би ико од нас престао да живи $\bar{u} о c e g y j y \hbar и ~ и ~ м у g р о с \bar{u}$ и интелигенцију и сазнање и сећање, потпуно и о свему, али без уживања, било малог било великог, затим без бола, и да буде сасвим неосетљив према свим таквим стварима“ (ЕК, В. Н. Цветковић). 4) „... Дај ми мудрости да чиним што је исправно и праведно. И учини ме 
оруђем своје воље“ (ЕК, www.rts.rs). 5) У име грађана Србије, молим поштеног налазача да уколико негде нађе изіуубљену

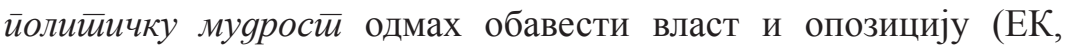
Политика). 6) Ко оспорава дејство звезда на судбину, оgбаиује Божју Мудрости и промисао (ЕК, М. Миланковић). 7) Ничеова лична трагика је у томе што је тај „иронијски отпор“ према себи самом, своју најлепшу и најдубљу муярости, на крају изиубио (ЕК, Р. Сафрански). 8) У минимуму потеза уме да ойкрије сву своју мудрост. Тако црта један Буда. Спокојно мирујући у себи, не узнемираван никаквом страшћу ... (О. Бихаљи-Мерин). 9) Мораћемо да тражимо начине како да избегнемо најгора решења и да редовно користиимо стрпљење, муярости, памет и снагу (ЕК, Политика). 10) Када вукове не можеш победити, онда завијај са њима. То је стара муярости коју сам покушао да искористиим у ироничном смислу речи (ЕК, Политика).

Beћ овде, у десетом примеру, наилазимо на метонимијску мотивисаност метафоре са којом ћемо се често сусретати у наставку. У питању је чињеница да се лексема муярости у томе случају односи на пословичну мисао „Када вукове не можеш победити, онда завијај са њима“. Дакле, мудрост овде има значење мудре мисли, тј. изјаве, те се при настанку наведене метафоре да уочити појмовна метонимија МУДРОСТ ЗА МУДРУ МИСАО 3 . У овој метонимији пак примећује се општије метонимијско начело ОСОБИНА ЗА МАНИФЕСТАЦИЈУ ОСОБИНЕ. Такође, у овоме последњем примеру уочавамо и ироничну, негативну употребу мудрости, која стоји у супротности са њеном позитивном конотативном вредношћу из претходних девет примера.

\subsection{1. МУДРОСТ ЈЕ ЛЕП / ДРАГОЦЕН ПРЕДМЕТ - МуДростИ} се може придавати и естетска вредност. У том смислу, она најпре може бити лейа. Затим, њена вредност може се оцењивайи, при чему она

3 Појмовна метонимија се од метафоре суштински разликује по томе што је за њену реализацију у језику потребан само један когнитивни модел (домен). Односно, општи образац појмовне метонимије гласи - „Х ЗА Y“ - при чему X означава појам који, у одређеном језичком контексту, нема само улогу да упућује на појам Ү, већ има за циљ и да омогућава његово разумевање. При томе, и један и други појам спадају у семантички опсег истог појмовног домена (Lakoff \& Johnson 1980: 36). 
Горан Ј. Петровић

може бити или веома gраїоцена, или сасвим обезвређена. Мудрост се

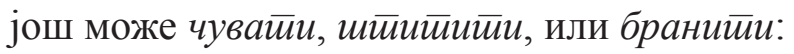

1) ... Не могу и душе немам да прећутим изузетну вреgносии и лейойу муяростии Његошевог Теодосија Мркојевића, која је основно и највише својство његове личности ... (ЕК, Политикин културни додатак). 2) Европа мора да чува јединство, солидарност и муgрости, поручио Валенса (ЕК, www.rts.rs). 3) Осим Његоша, Николај је тада помно читао и стваралачки оцењивао Ничеа и Достојевског, Шекспира и Гетеа, Маркса и Толстоја, Берклија и иняијску мудрости (ЕК, Православље). 4) ... Истакао је Бабић

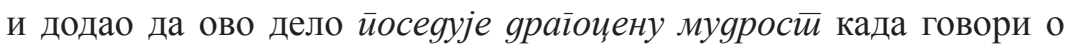
неким стубовима породице као што је мајка (EK, www.rts.rs). 5) Конзистентна подршка појединих уметничких кругова није могла да промени широко распрострањену навику да се обезвређују сви облици домородачке свести, њихово искуство, њихова уметност, њихова мудрости (ЕК, Политика). б) Док је бранила њихову мудрос $\bar{u}$ на сцени, ниједан сувишан покрет и ниједна сувишна мисао нису одвлачили пажњу од суштине изговореног (ЕК, Политика). 7) У основи, то је позивница да се прими тајно знање - зашишићена мудрости позната само одабраној неколицини (ЕК, Политика).

Када је реч о овој појмовној метафори, улогу изворног домена, у конкретном смислу, могу имати БИСЕРИ, БЛАГО, РИЗНИЦА и ТРЕ3OP:

8) Међу мислима за које је публика платила и до 400 евра по улазници нашли су се и следећи бисери мудросии $и$ „„Политика је врло значајна, али много тога у политици не ваља ... (EK, www. rts.rs)“. 9) Ако је Бог сада нашем реду поверио некакво послање, онда је оно у заустављању тог јуриша ка понору, у чувању, обнављању и одбрани оног блаїа мудросиии које су нам иреции завешишали, уздајући се у нас (ЕК, У. Еко). 10) Хипократово дело, најпре привидно обамрло у земљама Европе, дискретно сачувано на Истоку, ризници свих старих муgрости и, доживело је дуг пут ... (ЕК, В. Јеротић). 11) Зна се да су у њој садржани йрезори мудростии, лепоте и истине (ЕК, Политика). 
Израз бисери муяростии (девети пример) јавља се у ироничном смислу, а његова негативна конотација почива на томе што се некакве просте, одавно познате изјаве, издају за (лажну) мудрост. У преостала три примера $(9,10$, и 11$)$, мудрост има позитивну вредност. У сва четири примера поново препознајемо мотивисаност метафоре у виду метонимије ОСОБИНА ЗА МАНИФЕСТАЦИЈУ ОСОБИНЕ ${ }^{4}$. За разлику од првих седам реченица, у потоња четири примера мудрост се доживљава као некакав конкретан ДРАГОЦЕН ПРЕДМЕТ - бисер (8. пример), скупоцен метал / драги камен (имплицитно у 9. и 10. примеру), или новац 5 (11. пример). У деветом, десетом и једанаестом примеру, мудрости (тј. мудре реченице) јесу драгоцени предмети који се налазе у некаквом безбедном тродимензионалном затвореном про-

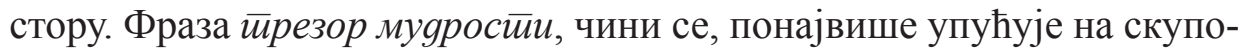
ценост мудрих мисли.

3.1.2. МУДРОСТ ЈЕ МАТЕРИЈАЛНО ДОБРО - Изворни домен ДРАГОЦЕНОГ ПРЕДМЕТА веома је сличан изворном домену МА-

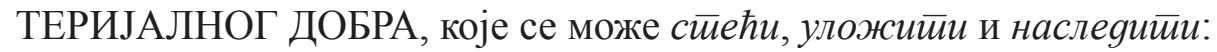

1) Уочи премијере Мирко Бабић рекао је новинарима како је сматрао да је после улога Прометеја, Светог Саве и краља

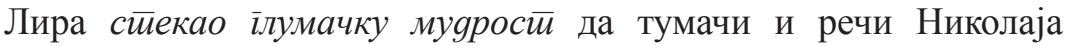
Велимировића (ЕК, Политика). 2) Председник Лилић је подсетио

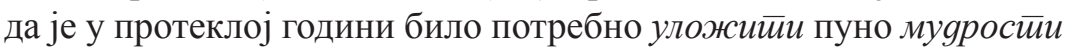
и одлучности да би се превазишле тешкоће са којима се суочавала СРЈ, и на међународном и на унутрашњем плану (ЕК, Танјуг). 3) Последњи изданак светородне лозе Немањића, по мајци, од њих је наслеgио и државничку муgрости, песнички дар, жудњу за слављењем Бога кроз задужбине, побожност и плаве очи загледане у вечност (ЕК, Политикин културни додатак).

4 Оваква метонимијска концептуализација мудрости не односи само мудре (или немудре) усмене изјаве. Метонимија мудРост ЗА мудРу изЈАвУ релевантна је и у писаном медију. Како бисмо то доказали, наводимо пример у коме уочавамо директну реализацију ове метонимије (без присуства икакве метафоре): 1) ... [Г]рафит: „Џаба сте кречили“. Ништа слађе младом вандалу него да свеже офарбани зид ижврља овом муgрошћу, по могућству црним спрејом (ЕК, Политика).

5 В. следећи одељак под насловом МУдРОСТ ЈЕ МАТЕРИЈАЛНО ДОБРО. 
Мудрост, као материјално добро, може бити високе (БОГАТСТВО / ИМЕТАК) или ниске (МИЛОСТИҢА) вредности:

4) Они су йребоїайи љуяском мудрошћу и човечном топлином, те је сваки други други иметиак од мање важности (ЕК, Политика). 5) $[\Pi$ росећи за њега у свемогућег Бога: дуг живот, постојано

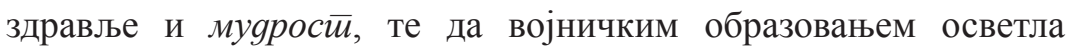
образ српству и обнови славу славних и храбрих предака својих неумрлог Цара српског племенитог Лазара Хребељановића (ЕК, Даница).

На основу петог примера закључујемо да мудрост, према православним Србима, долази од Бога, за кога, као дароватеља, она није тако многоцена као што је за човека, тј. за онога који милостињу прима.

Мудрост се још може концептуализовати и као РОБА коју човек

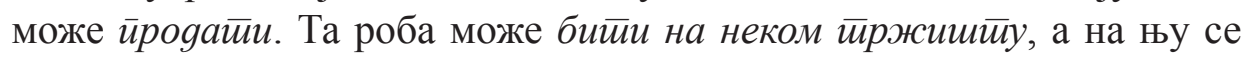
може и имайи монойол:

6) Кажу да не „,иpogajy“ велику муgрости и високоумну педагогију него само поштују децу (ЕК, Политика). 7) Зашто се поново меша са људима, зашто хоће да тамо изврши своје ослободилачко дело,

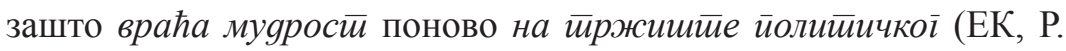
Сафрански)? 8) Канадски „Торонто стар“ хвали Обамину поруку свету да је „Џорџ Буш отишао и да Америка више не тврди да има монойол на муяроси"“ (ЕК, Политика).

Како је већ напред напоменуто, мудрост може бити НОВАЦ:

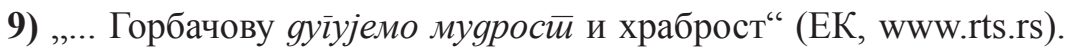

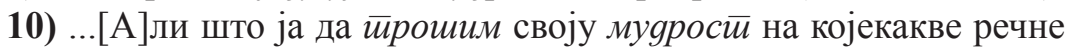
корњаче (ЕК, Р. Киплинг).

Она се може концептуализовати и помоћу домена НАГРАДЕ / ДАРА:

10) - Странче! - одговори Наусикаја Одисеју - по твојим речима видим да ниси прост човек и да су те богови наїраgили муgрошћу (ЕК, Н. А. Кун). 11) [У] намери да Ви образовани људи којима је и мудросй йоgарена сазнате истину, уделите правду и одлучите ... (ЕК, О. Б. Ињац). 
О МЕТАФОРИЧНОЈ КОНЦЕПТУАЛИЗАЦИЈИ МУДРОСТИ У СРПСКОМ ЈЕЗИКУ

Десети пример поново указује на схватање да мудрост потиче од божанства.

3.1.3. МУДРОСТ ЈЕ ОРУЖЈЕ - Овом појмовном метафором завршава се наш преглед концептуализације помоћу изворног домена предмета:

1) М. Матицки пише: „Данас се мали народ мора бранитии муgpouћy ...“ (ЕК, Даница). 2) Видим најмодернију кочију целокупног човечанства која наоружана муgрошћу неколико миленијума и праћена рефлекторима модерних научника креће у бајку златног доба обиља ... (ЕК, Политикин културни додатак). 3) Након демократских промена у СР Југославији, које је извојевао наш народ, одлучношћу и мygрошћу и невероватном снагом воље, наша земља изражава ... (ЕК, Политика). 4) Поменути француски писци били су омиљена лектира у младости Иве Андрића, писца који је освојио свеши муgрошћу и истанчаношћу своје прозе (ЕК, Политикин културни додатак).

Мудрошћу се, дакле, неко/нешто може бранийи, њоме неко може бити наоружан. Помоћу ње се нешто може извојевайи, а мудрошћу се чак може и освојий и свет. Посла имамо, очигледно, са менталном сликом некаквог рата, у коме особина мудрости служи као средство за борбу.

\subsection{4. КОНЦЕПТУАЛИЗАЦИЈА МУДРОСТИ ПОМОЋУ МАЬЕ} ТИПИЧНИХ ПРЕДМЕТА - Мудрост се може концептуализовати и као какав конкретан, мање типичан предмет:

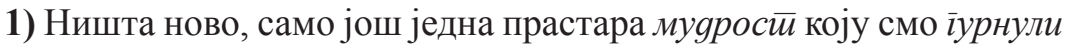
$\bar{u} о g$ йейих да би било лакше (ЕК, Политика). 2) Муgрости чами у иояруму док морбидна радозналост прави некрофилни спектакл откривања посмртне истине ко је какав био за време живота (ЕК, Политика). 3) Јужне обале тога полуострва и целу Сицилију населише Грци и тиме оgенуше ту полуварварску земљу - Рим се тада још налазио у доба свог нејаког детињства - йyрӣурним йлаштиом ірчке мудросиии и уметности (ЕК, М. Миланковић). 4) На пример: национално достојанство, интегритет државе, неповредивост територије. Кишобран муяросии (ЕК, Политика). 5) Али и да, с друге стране, старом муgрошћу иремерава нове 
Горан Ј. Петровић

књижевне творевине (ЕК, Политикин културни додатак). 6) Таква критика, против готових формула ветерана с йаиенйираном мygpowhy, допринела је ставу скепсе и негирања, који се, истина, понекад претварао у своју супротност ... (ЕК, Политика). 7) [Т]е смо сада и после ослобођења од највеће несреће која је задесила српски народ у ситуацији да морамо с великим стрпљењем и муgрошћу да кројимо следеће дане и недеље, мислећи даноноћно на наше генијалне дедове ... (ЕК, Политикин културни додатак).

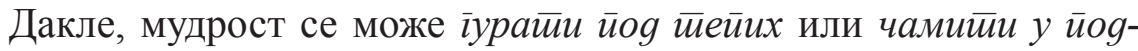

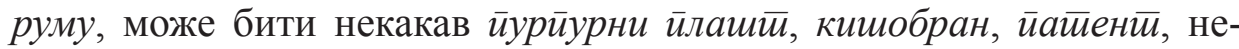
какво среgстиво за мерење, или пак мудрост могу бити маказе. Сви наведени примери садрже наш циљни појам у његовом позитивном значењу, изузев шестога, у коме се мудрост, чини се с негодовањем, представља као некакав патент чији изумитељи не дозвољавају било какве иновације на њему. Посебно су занимљиви трећи, четврти и седми пример. Док се у трећем указује на уврежено виђење да су Стари Хелени родитељи европске културе ${ }^{6}$, у четвртом се у први план истиче способност народа да се мудрошћу брани од политичке опасности (баш као се човек кишобраном штити од кише). У седмом примеру, народ мудрошћу ствара подношљиву будућност, као што какав кројач својим алатом ствара одговарајући одевни предмет. У првом и другом примеру, мудрост је некакав изузетно користан предмет који на неком забаченом месту стоји неупотребљив, док се пета реченица ослања на менталну слику занатлије који својим мерилом (мудрошћу) премерава димензије нечега (квалитет нове књижевности).

3.2. МУДРОСТ ЈЕ ГРАЪЕВИНА - Према нашем електронском корпусу, мудрост може представљати различите делове грађевине зграду, темељ зграде, стуб грађевине, или пак материјал од кога се грађевина зида.

1) ... Имај времена за читање - то је иеемељ муяросии “ (ЕК, Политика). 2) Зато америчке односе са светом превасходно хоће

6 Метафором МУдРОст ЈЕ ПУРПУРни ПЛАШТ указује се на драгоценост мудрости, јер су гримизни огртач, кроз историју, као обележје свога високог друштвеног статуса, носиле аристократе не само у Старој Грчкој, већ и у Феникији, Римском царству и Византији (Источном римском царству). 
да заснује на доброј старој яржавничкој мудросиии и дипломатској вештини, а не на наметању америчке воље и америчких вредности помоћу војне силе (ЕК, Политикин културни додатак). 3) [C] њима би се могло довести у везу и оно што се у симболичким

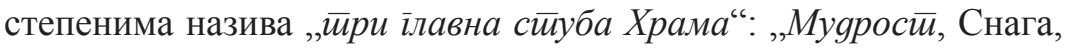
Лепота“" (ЕК, Р. Генон). 4) Тако размишља и главни јунак романа Јусуфа Чоловића, На ивици безgана, који вели: „Ваља нам уgарийи

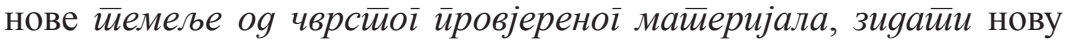
ірађевину, og старих искустава и муяростии, али уз помоћ нових генерација“" (ЕК, Република).

Дакле, у складу са закључцима Золтана Кевечеша везаним за појмове који се коцептуализују као сложени системи [COMPLEX ABSTRACT SYSTEM METAPHOR], мудрост се или сама може развијати и усложњавати (изграђивати), или пак може учествовати у изградњи некога другог, од себе већег конструкта (Kövecses 2010: 155-162).

3.3. МУДРОСТ ЈЕ ЖИВО БИЋЕ - У оквиру општег изворног домена ЖИВОГ БИЋА, мудрост се може представљати као ЖИВОТИњА (у најмањем броју случајева), затим као БИљКА (нешто чешће), и на крају као љУДСКО БИЋЕ (убедљиво најчешће).

3.3.1. МУДРОСТ ЈЕ ЖИВОТИҢА - Према нашем првом примеру, мудрост може некуда оgлешееии попут ПТИЦЕ. У следећа два примера, улогу изворног домена има некакво биће које бисмо равноправно могли држати и за животињу и за човека.

1) Постоји предање да је на Халевијевом гробу стајао запис: „Куда сте оgлешеле, веро, племенитости, скромности и муgростии (ЕК, М. Павић)? 2) Ствари не могу повриједити унутрашњост на апсолутан начин и ейикурејска мудрости живи од те истине (ЕК, Е. Левинас). 3) Кад је Миливојевић „констатовао“ да је добро бити у опозицији, јер „опозиционо деловање врло често буgи мудрости gалај ламе, али није добро кад нам лекције из морала држе они који су патентирали изборну крађу“ ... (ЕК, Политика).

\subsection{2. МУДРОСТ ЈЕ БИљКА}

1) Онај, пак, ко се смеје голим женама кад се тако вежбају ради

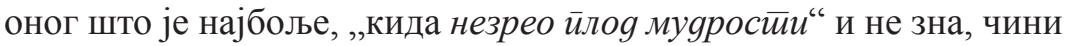


Горан Ј. Петровић

ми се, чему се смеје и шта ради (ЕК, Платон). 2) Зрна његове муяростии расуйа су по бројним интервјуима јер је увек био спреман да одговори и на најнепријатније питање (ЕК, Политика). 3) Предмети могу бити твоји савезници, али не садрже ни иррунке мудростии (ЕК, Политика). 4) „Четвртаст“ тип човека, чврсто

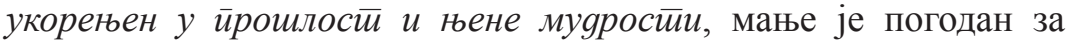
прилагођавање овим захтевима од „округлог“ и „глатког“ човека, дводимензионалне јединке без много историјских наслага, која боље трпи измештање са једног места на друго, свакодневне промене укуса и идола (ЕК, О. Станојевић). 5) Безбројне године испуниле су их поносом, укорењеном мудрошћу и злобом (ЕК, Џ. Р. Р. Толкин). 6) Одлуке о првој награди „Пресаg муgросиии“, за издавачки подухват и „Иницијал“ за најзапаженије издање, донеће жири у саставу ... (ЕК, Политика). 7) Он стајаше на томе мосту сам, Ватри и Сени скупа запркоси; штап му се сломи о тај

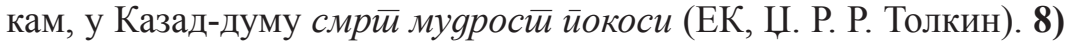
Је ли мудар ... По муяростии йасао би тираву (РСАНУ, Л. Костић).

Дакле, мудрост може представљати плодоносно дрво. Може бити скупина биљних зрна или трунки какве шишарке. У мудрост (прошлости) човек, попут биљке, може бити укорењен, а сама мудрост пак може бити укорењена (у човеку). Када се мудрост преноси са једног човека (или једнога поколења) на другог човека (или друго поколење), онда говоримо о концептуализацији мудрости помоћу некаквог биљног засада, који се може другде пресађивати. Видимо да се мудрост може концептуализовати помоћу целе биљке (било да је у питању дрвенаста или зељаста биљка), различитих делова биљке (зрна или трунки), или пак скупине биљака. Једино у нашем петом примеру мудрост не представља никакав биљни део, већ се она концептуализује као земљишна подлога у којој је човек „укорењен“. У седмом стиховитом Толкиновом примеру, мудрост се концептуализује као једна конкретна врста биљке-трава7 . Толкиновој реченици сличан је осми пример, у коме је реализована метафора МУДРОСТ ЈЕ ЛИВАДА.

На крају, док у изразу ,зрно мудрости“ увиђамо сличност ${ }^{8}$ са фразом „бисер мудрости““ (свако зрно јесте једна мудра изава), син-

7 Смрт се овде концептуализује у виду косача.

8 Мисли се на сличност у когнитивној структури наведених израза, а не на сличност у конотативном значењу, јер зрна муярости $и$ овде нису употребљена иронично,

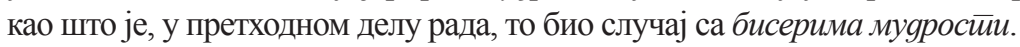


тагма „незрео плод мудрости“, која наговештава процес „сазревања“, тј. развијања мудрости, упућује на Кевечешеву МЕТАФОРУ СЛОЖЕНИХ АПСТРАКТНИХ СИСТЕМА о којој је већ било речи у одељку посвећеном метафори МУДРОСТ ЈЕ ГРАЋЕВИНА.

3.3.3. МУДРОСТ ЈЕ ЉУДСКО БИЋЕ - Концептуализација мудрости помоћу људског бића у нашем је корпусу заступљена великим бројем примера. На првом месту, мудрост уме да їовори:

1) Љубав нам говори да смо све на свету, а муgрости казује да нисмо ништа (ЕК, Политика).

Затим, мудрост, као какав наредбодавац, може од човека што захтевати, може му што налагати или што забрањивати. Мудрост, попут властодршца, може управљати нечијим поступцима, или имати своје изасланике:

2) Стога, пошто је мало размислила и дошла до закључка да

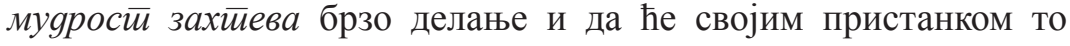
најбоље постићи, она без речи приђе столу и седе (ЕК, Џ. Остин). 3) Већ на основу тога йолитичка мудрости налаже уздржаност и меру у погледу захтева који се педстављају пред ДС ... (ЕК, Политика). 4) Али је остала још једна тајна чије је откриће муярости забрањивала (ЕК, Џ. Остин). 5) На сваки начин, као пријатељу, прво место у срцу оставићу вама, али нећу више да

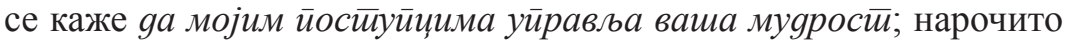
хоћу да се зна да сам изгубила сваки утицај на ваше одлуке (ЕК, Стендал). 6) У односу на путнике, као „изасланици железничке муяросии и" (како нас назва с правом озлојеђени путник Небојша у „Политици“ од 16.11), радимо оно што можемо ... (ЕК, Политика.)

Мудрост може подучавати, али и бити спасоносна, тј. може кога извести из неке непријатне ситуације:

7) „Два добра никада не иду заједно“, йоgучава древна муяростй (слободно препричана), чије је важење, посвему судећи, на истеку

9 У овом примеру, метафора мУдРОст ЈЕ УЧИТЕљИЦА мотивисана је меТОНИМИјОМ ДРЕВНА МУДРОСТ ЗА ДРЕВНЕ МУДРАЦЕ. 
(ЕК, Политика). 8) Стрпљење и рад, смиреност и мудрости могу нас извесии и, верујем у то, из дуготрајног периода буке и беса који нам је донео само јад, патњу, страх и жртве (ЕК, Политикин културни додатак).

Међутим, одређеним врстама мудрости могу се приписивати и негативне људске особине, нпр. пркос, лажљивост и полуученост:

9) Али удобна постеља и наїонска мудрости иела уройише се ироииив юеїове воље (ЕК, А. Кларк). 10) Одмах да ти кажем: све стиарачке мудросиии су лажљьие (ЕК, Д. Ћосић). 11) Покварена

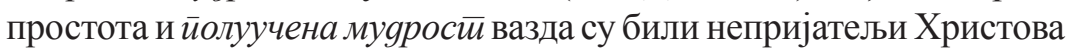
Божанства и Његова Јеванђеља (ЕК, Политикин магазин).

Наш први пример занимљив је по томе што се у њему једна врста мудрости - нагонска, телесна мудрост - концептуализује као једна посебна особа која, по свему судећи, борави у телу протагонисте и води бој против његове воље (која се такође представља као људско биће).

Мудрост, као и људи, може водити борбу и у тој борби она може или победити или бити побеђена:

12) Непосредно пошто су саопштени резултати гласања, Виденов је пред посланицима рекао да су данас у Народном собрању ,"иобеgили здрав разум, национална одговорност и gржавничка мудрости“ (ЕК, Танјуг). 13) Ко је икада помишљао да скепса може

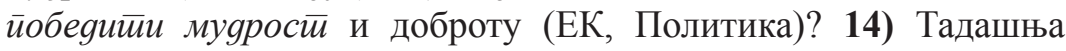
либерална влада у Јерусалиму је у повлачењу видела ииријумф мудростии (ЕК, Политика).

Мудрост, иначе, попут човека, може имати осећања, те је јој што може бити мрско:

15) Муgростии ништа није мрскије од претераног оштроумља (ЕК, Е. А. По).

Мудрост може бити и пратилац жене: 


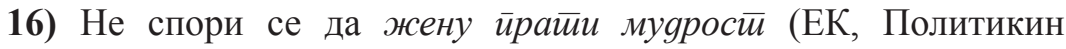
културни додатак).

Она може бити далековида:

17) Требало је имати не само смелости већ и gалековиgе муgростии да се, у садашњим приликама, стане иза такве поставке (ЕК, НИН).

Мудрост може бити мртва, а може и оживети. Нове мудрости могу сахранити старе:

18) ... Морела би положила своју хладну руку на моју, и из йейела

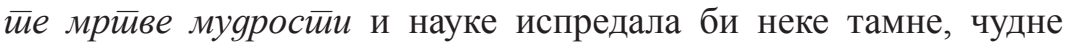
речи, чије се необично значење запечатило у мојој свести (ЕК, Е. А. По). 19) ... За савремене научнике и мислиоце то је на првом месту време оживљавања класичних учења и мудростии након дугог периода културног пропадања и стагнација (ЕК, С. Басара). 20) [И] тако су у њему јеgне мудростии сахраниле и заклониле gруіе , стиарије муяростии (ЕК, М. Павић) ${ }^{10}$.

Мудрост се, како сазнајемо из следећег помало вулгарног примера, може облачити на одређени начин:

21) [У] кафани се свашта лупа, ал' се убоде и понека мудра, макар у рогобатном облику. Али, мудрости, ионако воли да се тако обуче, иначе би свима била секси (ЕК, Политика).

Овде се мудрост, по свој прилици, представља као женска особа, која на себе „навлачи одело рогобатности“ како својом „голотињом“ не би изазвала „пожуду“. Помало је нејасна ова реченица, али биће да се њоме мудрачка озбиљност жели описати као неприкладна за кафанску атмосферу распојасаности. Уз то, видимо да се, у овом случају, лексема муgрости не односи на особину мудрости, већ на мудру изјаву, те је стога метафора МУДРОСТ ЈЕ ОБУЧЕНА ЖЕНА овде мо-

10 Овај, трећи пример посебно је илустративан, јер његова метафоричност почива на менталној слици једних, млађих људи, који сахрањују и, дословно, од погледа заклањају друге, старије и преминуле људе. 
Горан Ј. Петровић

тивисана метонимијски (ОСОБИНА ЗА МАНИФЕСТАЦИЈУ ОСОБИНЕ).

На крају, мудрост се може концептуализовати помоћу различитих родбинских односа:

22) - Јеси ли чуо кад, Водичка, да је оирезности мајка мудросиии (ЕК, J. Хашек). 23) Тако одзвања од нескривене ироније кад Сократ наводи песнике „као очеве муярости и и вође“, а да је Хомер васпитао читаву Хеладу, то је он са оштрином оспорио (ЕК, Х. Г. Гадамер). 24) „Маргиналије и моралије“ биће интерлудијум

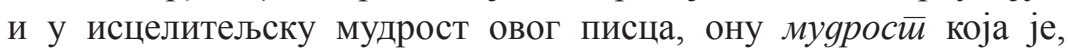
дидроовски речено, не само „,ћи искусшвва“ него и „наука о срећи“ (ЕК, Политика). 25) Неверници и секташи пуни су брига о осигурању овог кратког овоземаљског живота. Али ми, као gещ̧а

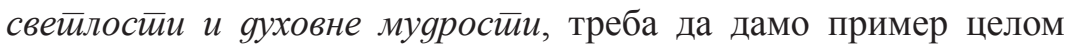
свету у тражењу, пре свега, Царства Небеског, које је вечито (ЕК, Православље). 26) Али су имали друге врлине: мудрост, лукавости

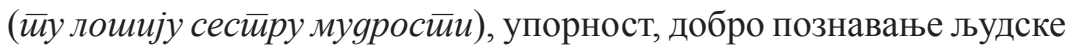
природе, смисао за организацију и опору духовитост (ЕК, О. Станојевић).

Видимо најпре да мудрост може имати мајку и очеве, односно она, још конкретније, може бити нечија кћи. Такође, мудрост може бити и родитељ (имати своју децу), а такође може имати и сестру. Наш последњи пример је особито занимљив, јер истовремено указује на сличности и разлике између мудрости и лукавства. Наиме, као што смо већ наговестили у почетном делу рада, и мудрост и лукавост подразумевају сналажљивост, тј. проницљивост; ипак, мудрост се сматра пожељном особином, док лукавство обично наилази на осуду околине.

3.4. МУДРОСТ ЈЕ МАТЕРИЈА - На почетку овог одељка наводимо неколико примера код којих није сасвим јасно о каквој је тачно врсти материје реч:

1) Била је потребна не мала gоза муgростии и визионарства да се у свој својој суштини препознају чарде, не само туристички бисери Војводине (ЕК, Политика). 2) Дивила сам се количини 
мудростии, здравог разума и снаге, који су му омогућили да ни у једном тренутку не поклекне нити пред једном провокацијом (ЕК, Политикин културни додатак). 3) Има Србија интелектуалног

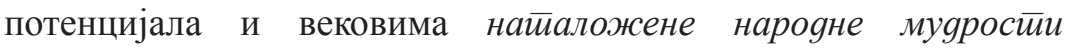
да дефинише своје националне и државне интересе ... (ЕК, Политика). 4) Али, ипак, то је акумулащија струке и муgросйи на једном месту (ЕК, Политика). 5) С тим што већи број речи, дубље

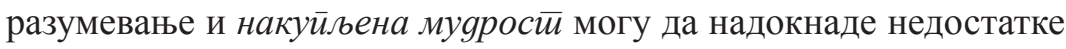
и представљају позитивне ефекте старења (ЕК, Политика). 6) Тада његова мати рече, йуна мудросиич: - Боље је црћи што пре, кад је човек већ бескористан и млитав (ЕК, Р. Петровић). 7) А имају и залиху муяростии и мудрих изрека које људи углавном нису никад чули или су их већ давно заборавили (ЕК, Џ. Р. Р. Толкин). 8) Муяросӣ раширена кроз сфере свемира није већа од мудрости у најмањим животињама (ЕК, М. Павић).

Ни у ком од наведених примера не можемо с потпуном сигурношћу рећи којом се то материјом концептуализује мудрост, јер би се у свакој од реченица могло говорити о најмање две врсте агрегатних стања. У том смислу, за „дозу мудрости“, на пример, типичан изворни домен би био некакав чврст или течан ЛЕК, за „наталожену мудрост“ то била некаква чврста, или получврста материја, за „количину мудрости“ чврста или течна, док би за „мудрост раширену кроз сфере свемира“" типична била некаква гасовита супстанца.

3.4.1. МУДРОСТ ЈЕ ТЕЧНОСТ - При концептуализацији мудрости помоћу ТЕЧНОСТИ, обично се мисли на прототипичног представника ове појмовне категорије - воду. У том смислу, мудрост може имати свој извор (врело). Затим, она може найајайи оне који су

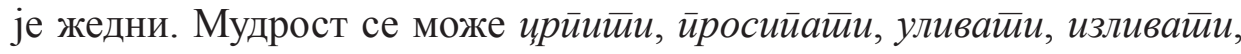

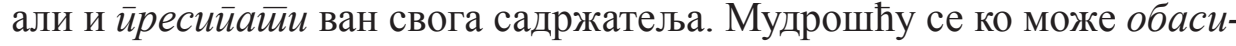
$\bar{u} а \bar{u} u$. Мудрост се, такође, сасвим експлицитно, може концептуализовати као РЕКА.

1) Тако се на двије Хегелове годишњице (1931. и 1970) могло констатовати да има безброј Хегела, и то не само различитих и противрјечних него и посве контрарних; ти извори муgросиии никад не ирресушују (ЕК, Политикин културни додатак). 2) [А]ли, 
Горан Ј. Петровић

у ствари, плашили смо се тог неисирйної врела знања, елоквенције и муяростии (ЕК, М. Поповић). 3) [И] да се не найајају само на националним и националистичким изворима, него и на Божанској мудростии, поштујући вере и својих комшија“ (ЕК, Политика). 4) $[\mathrm{A}]$ спис је - иако га је касније мештар у сласт појео сачуван у мом препису и доступан свима који су жеgни муяростии (ЕК, С. Басара). 5) Хуманисти настоје да се суоче са проблемима

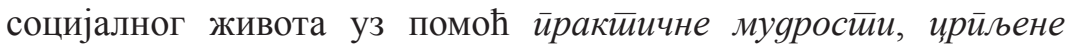
највећим делом из историје, књижевности и обичаја ... (ЕК, Политикин културни додатак). 6) Док чека нову снајку, чепрка по башти, сакупља јаја, сири сир и иросийа мудросиии за оне који желе да их чују ... (ЕК, Политика $)^{11}$. 7) Мелкијадес му је говорио о свету, покушавао да му улије своју стару мудрос $\bar{m}$, али је одбио да растумачи списе (ЕК, Г. Г. Маркес). 8) Док је, међутим, минхенски

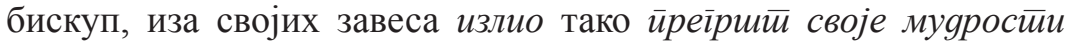
о земаљској љубави, награђен једним покорним осмејком и дирљивим подваљком стасите и млечне надвојвоткиње Софије ... (ЕК, М. Црњански). 9) Али муярости и ученост његова није така да би и на крају имала краја, него дотеравши до краја још се $\bar{u}$ ресийа ... (ЕК, Ђ. Даничић). 10) ... Глумица Ђурђија Цветић рекла је на комеморацији да је Раде Марковић био један од најбољих глумаца и да су његове колеге захвалне што је постојао и што их је обасийао својом духовитошћу, муgрошћу и шармом (ЕК, www.rts.rs). 11) [Р]омантичари место свега тога истичу народну поезију; траже у њој извор и уйоку мудросии и, сву етику и сву естетику ... (ЕК, Ј. Скерлић).

Мудрост се концептуализује помоћу још три врсте течности ВИНА, ЧОРБЕ и МЛЕКА:

1) Присталице празника луда као животног вентила некада су овако браниле своју карневалску слободу: „Сви смо ми људи слабо затворене бачве које прскају од вина мудростии, ако се то

11 Овај, шести пример, једини се одликује негативним значењем. Наиме, концептуализовати мудрост помоћу воде (извора живота) значи веродостојно описати насушност нашег циљног домена. У том смислу, није тешко докучити зашто израз „просипати мудрост“ има иронично значење. Објашњење гласи овако: просипање нечега тако драгоценог - воде - значи узалудно и беспредметно трошење речи. 
вино налази у непрестаном врењу страхопоштовања и страха од Бога. Потребно му је дати ваздуха да се не би покварило“ (ЕК, Политика). 2) „Гле ти њега, па то је врло интересантно. Шта ти тај све не зна! Сву је мудрости кашиком йосркао ..." (ЕК, Т. Ман).

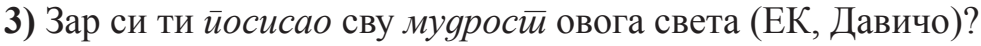

Први и други пример указују на чињеницу да се мудрост доживљава као материја која се налази у каквом САДРЖАТЕљУ (о метафори МУДРОСТ ЈЕ САДРЖАНИ ОБЈЕКАТ нешто више касније). Међутим, посебно је интересантан наш први пример, јер у њему уочавамо сложеност пресликавања - а) човек је слабо затворена бачва, б) човекова мудрост (уздржаност од телесних задовољстава) је вино које превире унутар бачве, в) човеков страх од Бога је превирање вина, г) окрепљујућа експлозија чулности је доток ваздуха у бачву (од кога вино остаје исправно). У трећем ироничном примеру мудрост је садржана у читавом свету, дакле у ОТВОРЕНОМ ДВОДИМЕНЗИОНАЛНОМ ПРОСТОРУ (више о овом изворном домену в. у пододељку 3.8.1.1.).

\subsection{2. МУДРОСТ ЈЕ ЧВРСТА МАТЕРИЈА}

1) Међутим, то није она „йракииччка мудрости“ стиароїа кова (ЕК, В. Н. Цветковић). 2) ... Хегел није објаснио, иако је говорио о историји као „месарском пању“ на који „бивају принесени на жрииву срећа народа, муярости яржава и врлина индивидуа“ (ЕК, А. Буха). 3) [В] елика заслуга за све животне успехе припада њиховим учитељима

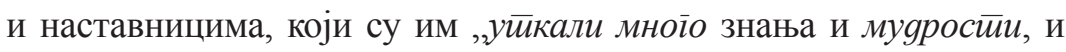
у свему били узор“ (ЕК, Политика). 4) Мој став је био да такве квалификације могу само да инфицирају, ослабе Запад, јер није у нарояну муяросй без потребе уйкано уйозорење: ко с ђаволом тикве сади о главу му се лупају (ЕК, Политика). 5) Коса му је сад била можда беља него онда, а његова брада и обрве били су можда дужи, и лище избразяаније бриїама и муgрошћу, али очи су му биле сјајне као и увек ... (ЕК, Џ. Р. Р. Толкин).

У првом примеру, мудрост је МЕТАЛНИ (вероватно ЧЕЛИЧНИ или ГВОЗДЕНИ) ПРЕДМЕТ. У другоме се мудрост описује као некаква ЖРТВА (живина или рогата стока) која се, како обичаји 
древних политеистичких али и појединих монотеистичких религија налажу, на месарском пању (тј. историји) приноси неком божанству на дар. У трећем и четвртом примеру уочљива је појмовна метафора МУДРОСТ ЈЕ ТКАНИНА, с тим што се у трећој реченици мудрост концептуализује као текстилни материјал који се може уткати у некога (ученике), док у четвртој видимо да је мудрост текстилни предмет у који се нешто (упозорење) може уткати.

Међутим, посебно је занимљив наш пети пример, у коме примећујемо присуство једне метонимије, али и двеју интересантних метафора. Наиме, мудрост је овде концептуализована метафорично (МУДРОСТ СУ БРАЗДЕ), а ова метафора мотивисана је метонимијски, будући да експресивне реакције описаног Толкиновог јунака (лице наборано од старости и забринутости) стоје за његову мудрост (ЕКСПРЕСИВНА РЕАКЦИЈА / НАБОРАНОСТ ЛИЦА ЗА ОСОБИНУ или СТАњЕ ДУХА / МУДРОСТ). При томе, Гандалфово лице се овде метафорички концептуализује као ИЗБРАЗДАНА ЊИВА.

Мудрост се још може концептуализовати као получврста, а полутечна материја.

6) Словенске пчеле из Грачанице, о којима је писао у једној од својих последњих књига, отишле су на своје последње путовање али су за собом оставиле меg муяросиии и љубави (ЕК, Политика). 7) Био је то дуел два максимално спремна ривала - донео је све оно лепо што овај витешки спорт може да пружи - еруйцију снаге, умећа, муярости $и$, упорности, жеље и достојанства и код победника и код побеђеног (ЕК, Политика).

Док се у првом примеру мудрост (заједно уз љубав) експлицитно представља као духовни МЕД којим се људи могу „сладити“, у нашој другој реченици мудрост се доживљава као неки од производа вулканске ерупције, највероватније ЛАВА. У потоњем примеру уочљива је метонимијска мотивација мудрости, с обзиром на то да се под овом лексемом у овом случају подразумевају мудри борилачки покрети (МУДРОСТ ЗА МУДРЕ ПОСТУПКЕ).

Мудрост се може концептуализовати и као ХРАНА или ПИЋЕ, с тим што, у вези са изворним доменом ХРАНЕ, у нашим примерима није сасвим јасно да ли је она чврста или течна: 
8) Пориија муяросиии - Маја Дивац из продукцијске куће „Мрежа“ уводи нас сваки дан у Европу емисијом „Еунет“... (ЕК, Политика). 9) На који начин, дакле, можемо имати поверења у историју и наслађиватии се њеном мудрошћу (ЕК, Л. Колаковски)?

Израз „порција мудрости“ семантички је сличан изразима „количина мудрости“ и ,доза мудрости“, само што се он, за разлику од потоње две синтагме, суштински односи на појмовни домен ХРАНЕ. У другом примеру, мудрост очито представља какву слатку намирницу (воће, на пример) или некакво слатко пиће (нпр. воћни нектар).

3.4.3. МУДРОСТ ЈЕ СВЕТЛОСТ - Мудрост се може концептуализовати као СВЕТЛОСТ која зрачи из некога ко је мудар, било да је у питању човек или Бог:

1) Дани посвећени пословима биће озарени веgрином мудростии (ЕК, Политика). 2) Одглумиће старијег човека наспрам Поцијевог надменог жутокљунца, користећи предност коју му дају висина и године, како би зрачио ауром найорно стиечене мудростии ... (ЕК, Мостови). 3) Ошитром свеиилошћу своје хлаяне иоейске муярости $и$, Брехт је увек указивао на несрећу коју доноси рат (ЕК, О. Бихаљ-Мерин). 4) Ко је био са обе стране, са ногама у паклу и йлавом при врху која исијава мудрости (ЕК, Политика)? 5) Нека би Господ подарио и нама чисто срце, нека би просвијетлио очи срца нашега и обасјао Својом Вјечном Муgрошћу и свјетлошћу нашу вољу окупану у дубинама чистога срца, да би онда ми у том светом тројству ума, осјећања и воље, сазнали и спознали свету и велику Тајну Свете Тројице, Оца и Сина и Духа Светога, Вјечнога ума Божјега, Вјечне Ријечи и Вјечнога Духа Божијега ... (ЕК, Православље). 6) У тридесетој години постао је игуман, а у четрдесетој учествовао је на Петом Васељенском сабору на коме је заблистиао својом ученошћу и муgрошћу (ЕК, Православље).

У шестом примеру реализована је сликовна метафора која глаСИ - ЧОВЕК КОЈИ РЕЧИМА ИСПОЉАВА МУДРОСТ ЈЕСТЕ ТЕЛО КОЈЕ БЛИСТА (ЗРАЧИ СВЕТЛОШЋУ). Овде је искоришћена чињеница да речи једног мудраца доводе до дословне блиставости лица код свих оних који отвореног срца слушају његове речи. При томе, подразумевамо да се и лице самог говорника одликује блиставошћу, 
услед стечене мудрости, тј. душевног мира. Дакле, поменута сликовна метафора мотивисана је метонимијом ЕКСПРЕСИВНА (И ФИЗИОЛОШКА) РЕАКЦИЈА ЗА ДУШЕВНО СТАЮЕ, оДНОсНО СЈАЈ У ЛИЦУ И ОЧИМА ЗА СТАЮЕ МУДРОСТИ. У свИХ шест примера уочавамо дубинско присуство метафоре ИДЕЈЕ СУ ИЗВОРИ СВЕТЛОСТИ [IDEAS ARE LIGHT-SOURCES], која је пак утемељена на метафори РАЗУМЕТИ ЗНАЧИ ВИДЕТИ [UNDERSTANDING IS SEEING] (оно што је осветљено боље се види, тј. разуме) (Lakoff \& Johnson 1980: 48).

3.5. МУДРОСТ ЈЕ ТАКМИЧАРСКА ДИСЦИПЛИНА - У мудрости се, као у каквој уметничкој или спортској дисциплини, људи могу надметати:

1) За генијалне Грке то је било још једно од йакмичењ $а$ муяростии, једино је Бијант ћутао (ЕК, Политика). 2) Титан који се са Зевсом наgмеша ао у мудростии, који људима доноси добра иако сам због тога мора да испашта, постаје заувек и потпуно побеђен (ЕК, Х. Г. Гадмер). 3) Платон ту мисли пре свега на конкурениее у „мудростичи“- софисте (ЕК, В. Н. Цветковић).

Наведени примери указују на чињеницу да је старогрчка цивилизација свесрдно неговала такмичарски дух међу својим мудрацима (философима).

\section{6. МУДРОСТ ЈЕ СИЛА}

1) Вођени смо били благошћу и муgрошћу старца Ивана Свјетова, руског емигранта, који је себе називао грађанином света (ЕК, Политика). 2) Христове су речи, како пева владика Николај, мудрост и сила. Силином йоgарене му муяросиии и лепотом љубави овај боготражитељ своју песничку реч узноси полетним тоном казивања (ЕК, Политика).

Први пример јасно указује на чињеницу да мудрост некога може водити, што је, заправо, суштинско својство некакве силе (пре људске, него природне). Други пример пак говори о мудрости која својом 
силином узноси песничку реч (примећујемо и то да се реч овде концептуализује као некакав предмет који се креће навише, по вертикалној линији). Дакле, мудрост је СИЛА која може кога водити или што узносити ${ }^{12}$.

3.7. КОНЦЕПТУАЛИЗАЦИЈА МУДРОСТИ ПОМОЋУ ВЕРТИКАЛНЕ СЛИКОВНЕ СХЕМЕ - Према Катарини Расулић (2004), у српском језику се, помоћу вертикалне просторне димензије ${ }^{13}$, може објаснити петнаест општих апстрактних домена. Када је реч о мудрости, релевантности имају три домена - ВРЕДНОСТ, МОЋ и РАЗВОЈ И СЛОЖЕНОСТ.

1) $[И]$ идеал изражен у антологијској песми „Федру“: „озбиљност, мера, мудра узвишеност, узвишена муярост"“" (ЕК, Политикин културни додатак). 2) Људи заборављају да је врхунска йолитичка

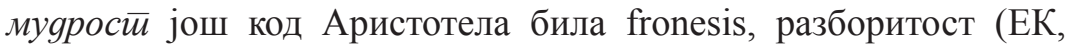
Пешчаник ФМ: Књига 1). 3) Кад је себи поставила једно друго питање, које можда не би могла спречити ни њена највећа мудрости, брзо се ослободила сваке неизвесности ... (ЕК, Џ. Остин).

Наведена три примера показују да свака врста мудрости, као нешто што има своју ВРЕДНОСТ, може да се пореди са осталим врстама мудрости, те да у складу са извршеном проценом иста може бити постављена на своје одговарајуће место на некаквој замишљеној вертикалној вредносној скали. Такву процену омогућава општа метафора МУДРОСТ ЈЕ ВРЕДНОСТ.

Поред лексема којима се експлицитно указује на сликовну схему вертикалности (узвишен и врхунски), и димензија величине (највећа мудрос $\overline{\text { }}$ ) јесте применљива на концептуализацију мудрости помоћу

12 Реч „узносити“ има углавном апстрактно значење (нпр. „узносити савремене научнике“ са значењем „величати њихове успехе“), али њен морфолошки састав (уз- + -носити) јасно сведочи о томе да је ова реч когнитивно зависна од човековог просторног искуства вертикалности (онај који је ГОРЕ вреднији је од онога који је долЕ).

13 Иначе, такве метафоре, засноване на биполаритету човековог просторног искуства (горе-доле, испред-иза, унутра-изван, итд), називају се оријенйационим мейафорама (Lakoff \& Johnson 1980: 14-21; Kövecses 2010: 40). 
вертикалне осе. Објашњење за претходну тврдњу лежи у човековом телесном искуству и гласи: „, ... позитивно телесно стање, односно здравље и живот, карактерише усправан положај човека (ГОРЕ), док негативна физичка стања, односно болест или смрт, подразумевају клонулост тела (ДОЛЕ)“ (Расулић 2004: 199). Односно, усправан положај тела се у нашој култури не доживљава само као нешто високо, већ се доживљава и као нешто велико, а о томе најбоље сведочи чињеница да се у српском језику висока особа често описује као велика особа. Дакле, димензије висине и величине јесу у односу корелације.

4) $[$ И] пошто је све таштина, и живот и уметност, он се обраћа Богу као врховној Муgростии и Истини (ЕК, Д. Киш). 5) [А] лопови, лажна суђења и лажни сведоци, удворице и улизице чине миље сваке власти која је похлепна и силничка, а коју наgвлаgавају женска мудрости, младост и лепота ... (ЕК, Политика). 6) Анализирајући све учеснике четвртфинала Обрадовић каже да су Хрвати једини заштитници „правог“ рукомета у којем вештина, муярос $\bar{u}$ и лепота gоминирају наg снаїом ... (ЕК, Политика).

У другој групи примера видимо да се мудрост налази изнад похлепне власти и снаге, као и да Божја мудрост има власт над свим осталим мудростима. Дакле, мудрост може бити моћнија у односу на нешто друго (при чему она заузима виши положај од тога са чиме се пореди), а исто тако, једна мудрост може имати моћ над свим другим мудростима. Иначе, према Расулићевој (2004: 252), у основи оријентационих појмовних пресликавања МОЋ JЕ ГОРЕ и НЕМОЋ/ЕНТИТЕТ У ОДНОСУ НА КОЈИ СЕ ИСПОЉАВА МОЋ ЈЕ ДОЛЕ Л ЖИ метафора MOЋ JЕ ФИЗИЧКА СНАГА. О томе зашто се физичка снага везује за ГОРЕ, ауторка наводи: „[У] физичкој борби онај ко је снажнији [јесте] горе, док је онај ко је слабији доле; виши раст често подразумева и већу снагу; а виши положај у простору повољнији је за интеракцију са околином, јер омогућава бољу прегледност и веће могућности за деловање“ (Расулић 2004: 252).

7) Па тако он и сад удари у излагање своје високе мудростии гласом и тоном окорелога професора ... (ЕК, Ј. Хашек). 
У овом нашем последњем примеру, „високу мудрост“ треба разумети као некакву професорску мудрост која би се, у исти мах, могла сматрати и вреднијом и мислилачки сложенијом у односу на мудрост необразованог човека. Дакле, појам ВРЕДНОСТИ је у корелацији са оријентационим метафорама РАЗВИЈЕНИЈЕ ЈЕ ГОРЕ, МАЮЕ РАЗВИЈЕНО ЈЕ ДОЛЕ; СЛОЖЕНИЈЕ ЈЕ ГОРЕ, МАҢЕ СЛОЖЕНО ЈЕ ДОЛЕ (Расулић 2004: 225). Поменуте оријентационе метафоре такође су утемељене на чињеници да се апстрактни појмови РАЗВОЈА и СЛОЖЕНОСТИ (која је обично последица развоја) поимају као ФИЗИЧКИ РАСТ (Расулић 2004: 225). Отуда употреба конкретног придева висок уз апстрактни појам мудрости.

\section{8. КОНЦЕПТУАЛИЗАЦИЈА МУДРОСТИ ПОМОЋУ ОДНО- СА САДРЖАВАҢА И НОШЕЊА \\ 3.8.1. ОДНОС САДРЖАВАҢА - Однос садржавања веома је ва-} жан за концептуализацију мудрости, при чему се мудрост може појмити или као САДРЖАТЕЉ или као САДРЖАНИ ОБЈЕКАТ. Наши примери, које ћемо укратко представити, јасно указују на схватање овога појма као тродимензионалног, затвореног или отвореног простора.

3.8.1.1. МУДРОСТ ЈЕ САДРЖАТЕЉ - Мудрост најпре може бити gубока, или иразна, што упућује на тродимензионални когнитивни простор овога појма:

1) Шекситирова мудросй толико је яубока да уочавање људског јада није ушкопило његову стваралачку енергију која вековима делује једнаким интензитетом (ЕК, Политика). 2) Успомене су слике без контекста: од ситуације у којој су настале, апстраховане

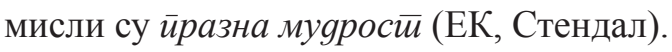

Мудрост, затим, може садржати моћ, време, животи, па чак и све шйо йосйоји, уколико се држи религиозно становиште. При томе, утисак је да се мудрост овде представља као затворени тродимензионални садржатељ, онај у коме су некакви драгоцени садржани објекти скривени од спољашности ${ }^{14}$ (Кликовац 2007).

14 У примеру број „четири“ садржани објекти, тј. време и рокови, који се налазе у божјој мудрости, за људе представљају тајну, односно, нешто скривено. 
3) Моћ Елроняова је у муяросиии, а не у оружју, речено је (ЕК, Џ. Р. Р. Толкин). 4) И не треба човек да се збуњује временима и роковима, јер је йајна времена и рокова у мудростии божјој, у предвиђању његовом и љубави његовој (ЕК, Ф. М. Достојевски).

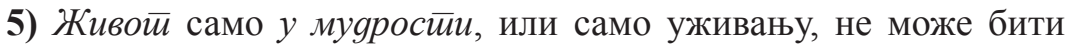
стварно (целовито; пуно) добро ... (ЕК, В. Н. Цветковић). б) Заправо, пре стварања, све је било у Боїу, у Божјој мисли и мудростии, Бог је стварао Мудрошћу и у Мудрости (ЕК, А. Коаре).

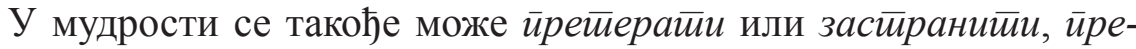

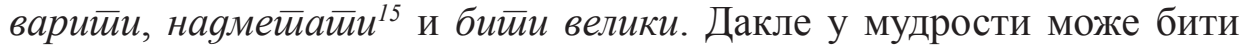
садржан и човек:

7) Свако ирретеривање или застирањивање, чак и оно у муяросиии (појмљеној као само-довољно знање) - штетно је, и за праведног човека - неприлично (ЕК, В. Н. Цветковић). 8) Немојте да се

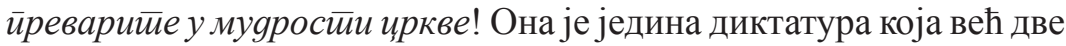
хиљаде година није срушена (ЕК, Е. М. Ремарк). 9) Фјолсвидир, „велик у мудростич“ (ЕК, А. Котерел).

Седми и осми пример занимљиви су по томе што откривају и негативне стране човековог „боравка“ у мудрости. Изрази „надметати се у мудрости“ у „бити велики у мудрости“ указују на изразито позитивно значење овог појма, јер се на основу њих стиче утисак о људима као некаквим малим ентитетима који, стремећи да прошире своје видике, покушавају да што више „порасту“ у свом садржатељу (поново је уочљива валидност вертикалне сликовне схеме).

На крају, мудрост се помоћу односа садржавања може представити и као нека област у коју се емигрира, област која би се, пре него тродимензионални, могла замислити као какав ОТВОРЕН ДВОДИМЕНЗИОНАЛНИ ПРОСТОР.

10) Након доласка у Канаду, ја сам још једном емиірирао у језик и муяростии Иве Андрића, Меше Селимовића, Милоша Црњанског, Данила Киша ... (ЕК, Политика).

15 За употребу ове лексеме в. одељак МУДРОСТ ЈЕ ТАКМИЧАРСКА ДИСцИПЛИНА. 
У складу са закључцима Душке Кликовац (2007), која се у једном свом раду позабавила семантиком предлога У и НА у српском језику, биће да је предлогом у овде поново означена скривеност, односно недокучивост мудрости великих писаца, при чему је реч „мудрости“, у множини, метонимијски мотивисана (МУДРОСТИ ЗА МУДРЕ ИЗЈАВЕ).

3.8.1.2. МУДРОСТ ЈЕ САДРЖАНИ ОБЈЕКАТ - Наши примери откривају да се мудрост може бити садржана у људском телу и људским делима:

1) Верујем да ћемо наћи у себи довољно мудростии, снаге и одговорности да не поклекнемо и да се одупремо искушењу власти по сваку цену ... (ЕК, Политика). 2) [И] подсетио на Павлову поруку, упућену „некима, сличним Јеврејима и Грцима“, да је у Исусовим делима саяржана божанска снаїа и мудрости (ЕК, Политика). 3) Упитао је Константина Филозофа зашто док говори увек држи књигу пред собом, док Хазари сву муgрости ваge из іруgи као да су је претходно прогутали (ЕК, М. Павић). 4) Покрсти се или ћемо ти муgрости свих књига које си прочитао

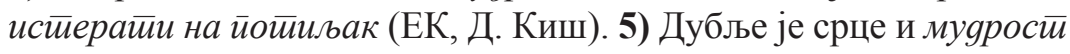
сриа неголи мудрости ума (ЕК, Православље).

Када је реч о људском телу као садржатељу мудрости, видимо да, поред општег израза „наћи мудрости у себи“, у средишту пажње могу бити глава, груди или, још конкретније, срце. Ови примери сагласни су са културолошки устаљеним „смештањем“ памети у главу, а осећања у срце, а сагласни су и са налазом ауторке Кликовац (2006: 191), која држи да се емоције у српском језику обично „лоцирају“ у грудни кош, тј. у срце, те ту замишљену тродимензионалну област назива унуйрашњим или емоционалним иростиором. С обзиром на то да бити мудар не подразумева само поседовање опсежног енциклопедијског знања, већ и владање сопственим осећањима, мудрост може бити садржана и у глави (уму) и у грудима (срцу).

\subsection{2. ОДНОС НОШЕЊА}

3.8.2.1. МУДРОСТ ЈЕ НОСИТЕЉ - Концептуализуја мудрости у виду носитеља повезана је са концептуализацијом овога појма по- 
Горан Ј. Петровић

моћу изворног домена ГРАЂЕВИНЕ, о чему је напред већ било речи. Сада наводимо два примера које у дотичном одељку нисмо представили, а у којима се мудрост представља као ТЕМЕЉ ГРАЪЕВИНЕ или ОСЛОНАЦ:

1) ...И стабилност у региону, која се не може іраgийи ни на ликовању, али на отпору, како је нагласио, већ на мудростии свих... (ЕК, Политика). 2) Јеротић је посебно истакао, ослањајући се на

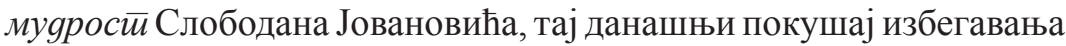
крајности у заузимању два искључива става... (ЕК, Политика).

Међутим, наводимо и један пример који није везан за изворни домен ГРАЂЕВИНЕ:

3) Па и да не постоје свега четири загонетна слова, која пре

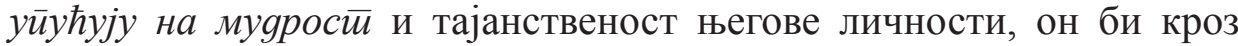
властито дело трајао (ЕК, Политика).

То што је уз глагол „упутити“ овде употребљен предлог „на“, чини се, сведочи о томе да дотична чтири слова казују тек понешто о мудрости особе о којој се говори. Такав утисак додатно је појачан употребом именице „тајанственост“. Да је којим случајем написано „упућују у мудрост“, онда би то вероватно подразумевало да се поменутим загонетним словима нешто детаљније открива мудрост поменуте тајанствене личности.

3.8.2.2. МУДРОСТ ЈЕ НОШЕНИ ОБЈЕКАТ - За ову метафору наводимо само један пример, у коме се каже да мудрост носе некакви симболи:

1) А муслиманска традиција нам јавља да је Сулејман, син Даудов, у свом двору имао сто сачињен од смарагдне плоче по којој су били уписани знаци који су носили сву мудрости света (ЕК, 3. Љ. Николић).

Биће да је употребљен однос ношења, а не однос садржавања, због тога што је овде вероватно реч о арапским стиховима из Курана, 
који су за припаднике исламске цивилизације у Отоманској царевини били разумљиви, па самим тим, у интерпретативном смислу, и доступни (насупрот нечему што није лако растумачити, те се стога концептуализује помоћу односа садржавања) (Кликовац 2007).

4. ЗАКЉУЧАК - Мудрост се може концептуализовати помоћу више различитих изворних домена, и то различитог степена општости. Приказ тих домена, класификован према нивоу општости, следи у Табели $1^{16}$ :

\begin{tabular}{|c|c|c|}
\hline $\begin{array}{l}\text { Изворни } \\
\text { Домени }\end{array}$ & Први ниво & Други ниво \\
\hline ПРЕДМЕТ & $\begin{array}{l}\text { 1) ЛЕП / ДРАГОЦЕН } \\
\text { ПРЕДМЕТ } \\
\text { 2) МАТЕРИЈАЛНО } \\
\text { ДОБРО } \\
\text { 3) ОРУЖЈЕ } \\
\text { 4) МАЮЕ ТИПИЧАН } \\
\text { ПРЕДМЕТ }\end{array}$ & $\begin{array}{l}\text { 1) БИСЕР, БЛАГО, РИЗНИЦА, } \\
\text { ТРЕЗОР } \\
\text { 2) БОГАТСТВО / ИМЕТАК, } \\
\text { МИЛОСТИЬА, РОБА, } \\
\text { НОВАЦ, НАГРАДА / ДАР } \\
\text { 4) ПУРПУРНИ ПЛАШТ, } \\
\text { КИШОБРАН, ПАТЕНТ, } \\
\text { СРЕДСТВО ЗА МЕРЕҢЕ, } \\
\text { МАКАЗЕ }\end{array}$ \\
\hline ГРАЪЕВИНА & $\begin{array}{l}\text { 1) ЗГРАДА } \\
\text { 2) ТЕМЕЉ ЗГРАДЕ } \\
\text { 3) СТУБ ЗГРАДЕ } \\
\text { 4) ГРАЪЕВИНСКИ } \\
\text { МАТЕРИЈАЛ } \\
\end{array}$ & / \\
\hline МАТЕРИЈА & $\begin{array}{l}\text { 1) ГАСОВИТА } \\
\text { 2) ТЕЧНА } \\
\text { 3) ЧВРСТА } \\
\text { 4) ПОЛУТЕЧНА- } \\
\text { ПОЛУЧВРСТА }\end{array}$ & $\begin{array}{l}\text { 2) ВОДА, РЕКА, ЧОРБА, } \\
\text { ВИНО, МЛЕКО, НЕКТАР } \\
\text { 3) МЕТАЛ (ГВОЖЪЕ), } \\
\text { ЖРТВЕНО МЕСО, } \\
\text { ТКАНИНА, БРАЗДА (НА } \\
\text { ЊИВИ), ХРАНА } \\
\text { 4) МЕД, ЛАВА }\end{array}$ \\
\hline
\end{tabular}

16 У колони насловљеној „Други ниво“, број испред сваке скупине појмова означава да наведени изворни домени јесу конкретизације општијег појма из претходне колоне са истим бројем („Први ниво“). 
Горан Ј. Петровић

\begin{tabular}{|c|c|c|}
\hline ЖИВО БИЋЕ & $\begin{array}{l}\text { 1) ЖИВОТИњА } \\
\text { 2) БИљКА } \\
\text { 3) ЉУДСКО БИЋЕ }\end{array}$ & $\begin{array}{l}\text { 1) ПТИЦА } \\
\text { 2) (ЧИТАВА) УКОРЕЊЕНА } \\
\text { БИЉКА, СКУПИНА ЗРНА, } \\
\text { ЗАСАД, ТРАВА, ЛИВАДА, } \\
\text { ЗЕМЉА (У КОЈОЈ ЈЕ } \\
\text { УКОРЕҢЕНА БИЉКА) } \\
\text { 3) НАРЕДБОДАВАЦ, } \\
\text { ВЛАСТОДРЖАЦ, } \\
\text { УЧИТЕЉИЦА, ВОЪА, } \\
\text { СПАСИТЕЈКА, ПРКОСНА / } \\
\text { ЛАЖЉИВА / ПОЛУУЧЕНА / } \\
\text { ДАЛЕКОВИДА / ОДЕВЕНА / } \\
\text { ОЖИВЕЛА ОСОБА, БОРАЦ, } \\
\text { ПОБЕДНИК, ГУБИТНИК, } \\
\text { ПРАТИЛАЦ ЖЕНЕ, } \\
\text { ПОКОЈНИК, ГРОБАР, ЧЕДО, } \\
\text { СЕСТРА }\end{array}$ \\
\hline \multicolumn{3}{|l|}{$\begin{array}{l}\text { ТАКМИЧАРСКА } \\
\text { ДИСЦИПЛИНА }\end{array}$} \\
\hline СИЛА & $\begin{array}{l}\text { 1) ВОДИЧ (љУДСКА } \\
\text { СИЛА) } \\
\text { 2) УЗДИЖУЋА } \\
\text { (ПРИРОДНА?) СИЛА }\end{array}$ & \\
\hline $\begin{array}{l}\text { ВЕРТИКАЛНА } \\
\text { СЛИКОВНА СХЕМА }\end{array}$ & $\begin{array}{l}\text { 1) ВРЕДНОСТ } \\
\text { 2) МОЋ } \\
\text { 3) РАЗВОЈ И } \\
\text { СЛОЖЕНОСТ } \\
\end{array}$ & \\
\hline ОДНОС САДРЖАВАњА & $\begin{array}{l}\text { 1) САДРЖАТЕЉ } \\
\text { 2) САДРЖАНИ ОБЈЕКАТ }\end{array}$ & $\begin{array}{l}\text { 1) ЗАТВОРЕНИ } \\
\text { ТРОДИМЕНЗИОНАЛНИ } \\
\text { ПРОСТОР, ОТВОРЕНИ } \\
\text { ДВОДИМЕНЗИОНАЛНИ } \\
\text { ПРОСТОР, ЉУДСКА ДЕЛА, } \\
\text { ЉУДСКО ТЕЛО (ГЛАВА / } \\
\text { ГРУДИ) }\end{array}$ \\
\hline ОДНОС НОШЕЊА & $\begin{array}{l}\text { 1) НОСИТЕЉ } \\
\text { 2) НОШЕНИ ОБЈЕКАТ }\end{array}$ & $\begin{array}{l}\text { 1) ТЕМЕЉ / ОСЛОНАЦ } \\
\text { ЗГРАДЕ, ПИСАНИ ЗНАЦИ }\end{array}$ \\
\hline
\end{tabular}

У појединим случајевима, при настанку појмовних метафора уочена је метонимијска мотивација, и то посредством следећих двеју појмовних метонимија: 1) МУДРОСТ ЗА МУДРУ ИЗЈАВУ и 2) МУДРОСТ ЗА МУДРЕ БОРИЛАЧКЕ ПОКРЕТЕ (за обе меТонимије шире метонимијско начело гласи: ОСОБИНА ЗА МАНИФЕСТАЦИЈУ ОСОБИНЕ). Такође, појмовна метонимија је, као средство мотивације, препозната и у јединој препознатој сликовној метафори. Сликовна метафора о којој говоримо гласи: ЧОВЕК КОЈИ РЕЧИМА 
О МЕТАФОРИЧНОЈ КОНЦЕПТУАЛИЗАЦИЈИ МУДРОСТИ У СРПСКОМ ЈЕЗИКУ

ИСПОљАВА МУДРОСТ ЈЕСТЕ ТЕЛО КОЈЕ БЛИСТА (ЗРАЧИ СВЕТЛОШЋУ), а њена метонимијска мотивација јесте: СЈАЈ У ЛИЦУ И ОЧИМА ЗА СТАҢЕ МУДРОСТИ (шире метонимијско начело: ЕКСПРЕСИВНА И ФИЗИОЛОШКА РЕАКЦИЈА ЗА ОСОБИНУ / ДУХOВНО СТАњЕ).

У смислу конотативних вредности МУДРОСТИ, може се рећи да је реч о особини која се углавном сматра изузетно пожељном, с тим што се повремено, у случају поистовећивања мудрости са лукавством, на овај појам гледа с негодовањем. Такође, мудрост се каткад користи у у ироничном смислу, са снажном негативном конотацијом, а у сврху подсмевања онима који као мудрост представљају безумље.

Како би се овај апстрактни појам, са когнитивистичке тачке гледишта, још подробније испитао, потребно би било проучити и случајеве у којима је метонимија директно реализована (примера ради, в. четврту фусноту). У сваком случају, ово истраживање открива барем најосновније аспекте појмовног структурисања МУДРОСТИ у српском језику. Најзначајнији од тих аспеката свакако су схватања о драгоцености и скровитости мудрости, схватања која су похрањена у самом српском језику, те самим тим и у појмовном систему говорника тог језика, односно свих оних људи којима српски језик бар донекле обликује поглед на свет.

\section{Литература}

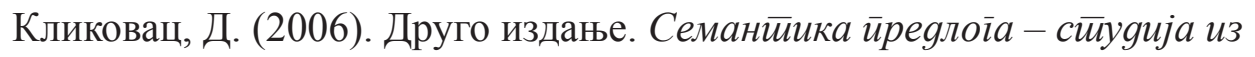
коїнийивнелинівистиике. Београд : Филолошки факултет.

Кликовац, Д. (2007). „Предлошка значења у настави српског језика као страног: случај предлога У и НА“. [У Зборнику] Срӣски као сиирани језик у йеорији и иракси (стр. 47-63). Београд : Филолошки факултет, Центар за српски као страни језик у теорији и пракси.

Кликовац, Д. (2008). Шта је то метафора?. Књижевност и језик LV/12: $57-76$.

Kövecses, Z. (2010). Second edition. Metaphor: A Practical Introduction. 
Oxford : Oxford University Press.

Lakoff, G. \& Johnson, M. (1980). Metaphors we live by. Chicago : The University of Chicago Press.

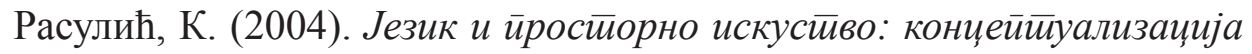
верииикалне gимензије у енїлеском и срйскохрвайском језику. Београд : Филолошки факултет, Београд.

\section{Извори}

ЕК - Елекйронски корйус савременої срйскої језика. Верзија SrpKor 2013. Copyright: Група за језичке технологије Универзитета у Београду. Аутори: Витас, Душко и Утвић, Милош. Доступно на: http://www.korpus.matf.bg.ac.rs/ [10.09.2015.]

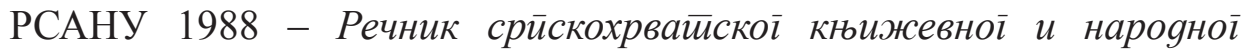
језика. Књига XIII: Моире-наклайуша. Београд : Институт за српскохрватски језик (1988).

Ћосић, П. (2008). Речник синонима. Београд : Kornet.

Goran J. Petrović

\section{Resume}

\section{ON THE METAPHORICAL CONCEPTUALISATION OF WISDOM IN SERBIAN}

The author analyses the conceptualisation of WISDOM in the Serbian language. In theoretical terms, the paper is based on the cognitive linguistic Contemporary Metaphor Theory. Prior to commencing his analysis, the author set himself the three following goals -1 ) to establish a list of source domains employed for the metaphorical conceptualisation of WISDOM, 2) to recognise and single out the conceptual metonymies participating in the emergence of conceptual metaphors, and 3) to point out the image metaphors which make any use of WISDOM for their target domains. For the semantic definition of WISDOM the researcher relied on the Serbo-Croat Literary and Colloquial Language Dictionary (Book XIII) published by the Serbian Academy of Sciences and Arts. In addition, a smaller portion of the employed linguistic examples was retrieved from the said dictionary, whereas a huge majority of them came from the 2013 Electronic Corpus of Contemporary Serbian. There are four different 
results of the analysis. First of all, in Serbian WISDOM is conceptualised by a considerable number of source domains, which, for their part, can be classified into three different levels according to how general or specific they are. For instance, the most general category is made up of eight different source domains (e.g. OBJECT, BUILDING, MATTER, PLANT, etc.). Secondly, the author found two metonymies partaking in the emergence of some metaphors (e.g. WISDOM FOR WISE THOUGHT). Thirdly, one metonymically motivated image metaphor was indentified (A PERSON SPEAKING WISELY IS A BODY EMANATING LIGHT). And last but not least, on most occasions WISDOM has a strong positive value in Serbian, whereas sporadically it may also appear in its two negative meanings -1 ) when signifying cunningness or 2) when used ironically.

Key words: conceptual metaphor, image metaphor, metonymic motivation of metaphors, conceptualisation, wisdom, source domain, spatial schema of verticality 